\title{
NEW TUTORS' PERSPECTIVE ON MOODLE PERFORMANCE: A CASE STUDY IN UNIVERSITAS TERBUKA
}

\section{Siti Hadianti}

Universitas Terbuka, Indonesia

Email: sitihadianti@ecampus.ut.ac.id

\begin{tabular}{|c|c|}
\hline Info Artikel & Abstract \\
\hline $\begin{array}{l}\text { Sejarah Artikel: } \\
\text { Diserhakan } 2 \text { Maret } 2020 \\
\text { Direvisi } 8 \text { Oktober } 2020 \\
\text { Disetujui } 15 \text { Oktober } 2020\end{array}$ & $\begin{array}{l}\text { The purpose of this study was to investigate the perspective of new tutors using Moodle at } \\
\text { the Universitas Terbutka (UT). } \\
\text { This study uses a qualitative method with a case study design. The research informants } \\
\text { were seven new UT lecturers with different educational backgrounds. Researchers used a } \\
\text { questionnaire to investigate new tutor perspectives on Moodle's performance. The } \\
\text { questionnaire is closed which consists of } 8 \text { questions. In the questionnaire, the researcher }\end{array}$ \\
\hline $\begin{array}{l}\text { Keywords: } \\
\text { new tutors, } \\
\text { moodle, } \\
\text { e-learning }\end{array}$ & $\begin{array}{l}\text { agree, doubt, disagree, strongly disagree. In applying the questionnaire, the researcher } \\
\text { took two steps. First, researchers distributed questionnaires to study participants. Second, } \\
\text { researchers began to extract, analyze, and conclude the data that had been collected using } \\
\text { a questionnaire. In extracting data from the questionnaire, the researcher developed an } \\
\text { analytical method based on Dey's theory which consists of describing phenomena, } \\
\text { classifying them, and seeing how our concepts are related. } \\
\text { The results reveal that there are three main things in relation to the new tutor's } \\
\text { perspective: friendly to use, simple modification features, and convenient assessment tools. } \\
\text { The results of this study are a major concern for tutors because this aspect is an important } \\
\text { part that can support teaching and learning activities when using Moodle. }\end{array}$ \\
\hline
\end{tabular}

\begin{abstract}
Abstrak
Tujuan penelitian ini yaitu untuk menginvestigasi perspektif tutor baru dalam menggunakan Moodle di Universitas Terbuka (UT).

Penelitian ini menggunakan metode kualitatif dengan desain studi kasus. Informan penelitian yaitu tujuh orang dosen UT baru dengan latar belakang pendidikan berbeda. Peneliti menggunakan kuesioner untuk menyelidiki perspektif tutor baru tentang kinerja Moodle. Kuesioner bersifat tertutup yang terdiri dari 8 pertanyaan. Dalam kuisioner, peneliti memodifikasi pertanyaan dengan mengklasifikasikan range respon dengan 5 skala: sangat setuju, setuju, ragu-ragu, tidak setuju, sangat tidak setuju. Dalam mengaplikasikan kuesioner, peneliti melakukan dua langkah. Pertama, peneliti menyebarkan kuesioner kepada partisipan penelitian. Kedua, peneliti mulai mengekstraksi, menganalisis, dan menyimpulkan data yang telah dikumpulkan dengan menggunakan kuesioner. Dalam menggali data dari kuisioner, peneliti mengembangkan metode analisis berdasarkan teori Dey yang terdiri dari mendeskripsikan fenomena, mengklasifikasikannya, dan melihat bagaimana kita konsep saling berhubungan.

Hasil penelitian mengungkapkan bahwa ada tiga hal utama dalam kaitannya dengan perspektif tutor baru: ramah digunakan, fitur modifikasi sederhana, dan alat penilaian yang nyaman. Hasil penelitian tersebut merupakan perhatian utama bagi para tutor karena aspek tersebut adalah bagian penting yang dapat mendukung kegiatan belajar mengajar ketika menggunakan Moodle.
\end{abstract}




\section{Siti Hadianti \\ NEW TUTORS' PERSPECTIVE ON MOODLE PERFORMANCE: A CASE STUDY IN ... \\ REFLEKSI EDUKATIKA : Jurnal Ilmiah Kependidikan, Volume 11, Nomor 1, Desember 2020, hlm. 35-39}

\section{INTRODUCTION}

Universitas Terbuka (UT) as the only open and distance university in Indonesia has tried various ways to improve its implementation in teaching learning activity. To equip the students with the newest trend in technology and improve their knowledge and skills, UT provided its students with several additional learning services. One of the learning services that help students to support the independent learning process is the E-learning.

Merging face-to-face learning with this elearning concept allows learning quality to improve significantly. In addition, it will also encourage students to study independently. On the other hand, it inspires tutors to be more creative and innovative in communicating and integrating learning materials by using information and communication technologies.

The interaction that awakens between lecturers and students in online learning (elearning) allows tutors to compile and adapt strategies of teaching and learning materials and providing encouragement to students during the learning process (Cole and Foster, 2008).

In addition, tutors (lecturers) through elearning can implement a learning strategy through the contractivity approach, learning based on various sources, learning collaboration, learning by problem, learning by case and learn contextually by leveraging the tools that available from the Moodle e-learning platform. (Wihadanto, et.al, 2016).

The online tutorial is one of the e-learning services that students can use during the teaching learning process. For every subject, it consists of 8 sessions that last for 2 months (1 registration period). Students and tutors will be given username and password to login into the elearning UT website and access the online tutorial.

Online tutorial is supported by the Moodle (Modular object-oriented dynamic learning environment) platform. According to Yildiz, et.al (2018), Moodle is a learning management system that can be easily used by all users for the online lesson and course management system that can respond to the needs related to online teaching.

As one of the most widely used opensource e-learning platforms, Moodle enables the creation of a course website and ensuring it can be accessed only by the enrolled students. Furthermore, Jebari (2017) explained that the multimedia tools offered by Moodle allow to create interactive and attractive activities making the learning process easier for students.

The use of Moodle is already widespread in all levels of education, from primary schools to universities. It gains popularity because it is free, flexible, customizable, and basically contains many standard features which is very useful for the users. Today, more than 54,000 active sites are registered from 225 countries, with millions of users and it is available in more than 100 languages (Moodle, 2015).

Domenico (2016) added that by using Moodle, teachers can make learning material, quiz, electronic journal, etc. Students can also access it easily so that it can be more effective and efficient. It is in line with many experts who state that Moodle has several main features such as survey, questionnaire, assignment, chat, forum, post, workshop, and can create collaborative text.

Moodle is an open source platform that can build effective online learning. The tutors are able to organize collaborative learning activities on the website. In addition, Moodle facilitates a wide range of online learning features to make it easier for users to develop online tutorial applications.

Online tutorials that run effectively require 'individual competences' (tutor/lecturer). 'Individual competences' in this case is the ability of a tutor (lecturer) to use and utilize 'e-learning' in the learning process (Wihadanto, et al, 2016). The tutor should have knowledge, adaptability, and skills to information technology communication, particularly e-learning literacy. They also required to arrange the strategy of teaching and presentation of the materials to be taught in the Moodle platform.

One example of e-learning literacy is to present the material for specific learning. These e-learning literacy including uploading materials, give discussion and feedback, and develop objective and task tests (homework). All of these activities are done by utilizing Moodle platform features in accordance with the learning strategy.

The online tutorial using Moodle provides a variety of features (tools) that is installed to support the learning strategy. Unfortunately, these features have not been fully used and maximally utilized by tutors (lecturers). It can be caused by the limited knowledge and skills of tutor (lecturer) in operating and using the elearning.

It is acceptable when the user (tutor/lecturer) can operate a variety of features (tools) installed on the platform (Moodle) used. 


\section{Siti Hadianti \\ NEW TUTORS' PERSPECTIVE ON MOODLE PERFORMANCE: A CASE STUDY IN ... \\ REFLEKSI EDUKATIKA : Jurnal Ilmiah Kependidikan, Volume 11, Nomor 1, Desember 2020, hlm. 35-39}

It is precisely based on the learning needs, competencies, characteristics of content or teaching materials, and integrate it through the features available in the online tutorial platform for the online learning process.

In Universitas Terbuka, all the tutors have access to the online tutorial and they have responsibility to manage the subjects assigned by the faculty dean. Tutors are including the UT lecturers and recruited tutors (non-UT tutors). Non-UT tutors are university lecturers other than UT, high school teachers, practicioners, and others who meet the requirements.

However, this study is focused only on the UT lecturers. In 2019, UT accepted new lecturers whom are civil servant candidates. For the new UT lecturers who are assigned as tutor, it will be challenging for them to use the platform. Assuming most of them are not familiar with the Moodle before, short trainings have been conducted to assure that all the new UT tutors can operate the Moodle because it is very important for the online tutorial to be done effectively. This research aim to investigate the new UT tutors perspective on the Moodle performance.

\section{RESEARCH METHODOLOGY}

The purpose of this study is to investigate new tutors' perspective on the use of Moodle in UT. Based on the objective, the researcher used a qualitative method with a case study design. According to Creswell "qualitative research is a means for exploring and understanding the meaning individual or group ascribe to a social or human problem". The research design was considered suitable since the researcher tended to discover new tutors' perspective when they use Moodle. The participants were 7 new UT lecturers with different education background. They are civil servant candidates who have served for almost a year in UT and becoming an online tutorial tutor.

The research was conducted in Universitas Terbuka (UT), Indonesia. The reason for choosing this place was because the university has just recruited new lecturers who served as tutor. Therefore, they automatically act as new tutors who are suitable as the participant of this research.

The researcher used questionnaire to investigate the new tutors' perspective on
Moodle performance. The questionnaire is a close-ended that consists of 8 questions. In the questionnaire, researcher modified the question by clasifiying the range response with the 5 scales: strongly agree, agree, undecided, disagree, strongly disagree.

In applying the questionnaire, researcher conducted two steps. First, researcher distributed the questionnaire to the research participants. Second, researcher started to extract, analyze, and conclude the data that has been gathered by using questionnaire. In exploring the data from the questionnaire, researcher developed an analysis method based on the theory of Dey (1993, p. 31) who stated that the core of qualitative analysis lies in the related processes of describing phenomena, classifying it, and seeing how our concepts interconnect. It means that researcher analyzed the data according to several step such as describing the phenomena, classifying it based on the objective of the research, and concluded it.

\section{RESULT AND DISCUSSION}

The researcher used questionnaire to investigate the new tutors' perspective on Moodle performance. The new tutors are required to answer all the 8 questions where they must choose among the 5 alternatives that are provided: strongly agree, agree, undecided, strongly disagree, disagree. The results of the questionnaire are summarized on the table below:

Table 1. Questionnaire Result

\begin{tabular}{|c|c|c|c|c|c|}
\hline Question & SA & A & U & D & SD \\
\hline $\begin{array}{l}\text { Learning through } \\
\text { UT E-learning is } \\
\text { convenient and easy } \\
\text { to use }\end{array}$ & 25 & 62.5 & 12.5 & & \\
\hline $\begin{array}{l}\text { I can operate UT E- } \\
\text { learning without } \\
\text { constraint }\end{array}$ & 37.5 & 50 & 12.5 & & \\
\hline $\begin{array}{l}\text { I can use/access UT } \\
\text { E-learning } \\
\text { anywhere }\end{array}$ & 37.5 & 62.5 & & & \\
\hline $\begin{array}{l}\text { As a lecturer, E- } \\
\text { learning can make } \\
\text { me teach better than } \\
\text { ever }\end{array}$ & 12.5 & 50 & 37.5 & & \\
\hline $\begin{array}{l}\text { The features of UT } \\
\text { E-Learning are easy } \\
\text { to adjust to your } \\
\text { needs }\end{array}$ & 12.5 & 37.5 & 37.5 & 12.5 & \\
\hline $\begin{array}{l}\text { I have full control } \\
\text { over the E-learning } \\
\text { feature I manage. }\end{array}$ & 25 & 50 & 25 & & \\
\hline $\begin{array}{l}\text { I can assess student } \\
\text { performance easily }\end{array}$ & 50 & 25 & 25 & & \\
\hline $\begin{array}{l}\text { I can add/change } \\
\text { assessments as } \\
\text { needed. }\end{array}$ & 37.5 & 62.5 & & & \\
\hline
\end{tabular}




\author{
Siti Hadianti \\ NEW TUTORS' PERSPECTIVE ON MOODLE PERFORMANCE: A CASE STUDY IN ... \\ REFLEKSI EDUKATIKA : Jurnal Ilmiah Kependidikan, Volume 11, Nomor 1, Desember 2020, hlm. 35-39
}

Description:

SA: Strongly Agree

A : Agree

$\mathrm{U}:$ Undecided

D : Disagree

SD: Strongly Disagree

Out of 7 tutors, $60 \%$ answered they have ever become lecturer in conventional university while $40 \%$ said they are brand new lecturer. The next question is whether they have ever used Moodle before working in UT and $87.5 \%$ stated that they have never use Moodle, while the rest of the participants that are $12.5 \%$ stated yes. The application that they have ever used by using Moodle platform is Edmodo. The next question is whether the new tutors have ever got training on how to use Moodle. Almost $13 \%$ answered that they never get training while the other $87.5 \%$ said they have got the training.

From the questionnaire, researcher extract some data which can be concluded as primary finding of this research. The findings were explained elaborately below:

\subsection{New tutors' Perspective}

As the new user of Moodle, the tutors must adapt quickly with the platform. The researcher revealed the finding in 3 main areas: userfriendliness, simple modification features, and convenient assessment tools from the new tutors' perspective which has been rarely discussed.

\subsubsection{User-friendliness}

Based on the questionnaire, it is revealed that $62.5 \%$ of the respondents agree that learning through Moodle is convenient and easy to use. To support this idea, it can be seen from the table that $50 \%$ of the participants agreed that they can operate Moodle without constraint. They also can access it anywhere supported by the $62.5 \%$ of the new tutors' response in the questionnaire.

The statement is in accordance with Yildiz, et al (2018) who stated that one of the advantages of Moodle is that it is user-friendly. Nowadays, particularly in online courses, it is easy to use the Moodle platform by simply registering and then adding account information. In a broader context, platform users can easily access relevant online courses from anywhere in the world at any given time. In this sense, the independence of time and place is accompanied by the autonomous learning of learners as well as learning environments that support cooperation.

This result finding about user friendliness endorses Chewe's research result (2018). The scholar showed that regarding the user friendliness of Moodle platform as a teaching tool, majority of the respondents (21 people) agreed that Moodle was user friendly, 13 disagreed, 5 strongly disagreed and 3 strongly agreed that it was user friendly.

\subsubsection{Simple Modification Features}

There are a lot of features in the Moodle platform. Almost $38 \%$ percent of the participants agreed that the features of UT E-learning are easy to adjust to their needs. In addition, $50 \%$ respondents stated that they have full control over the E-learning feature they manage.

Florian (2010) discussed a variety of virtual options for schools with respect to virtual learning environments and concluded that Moodle is optimal for institutions because of its constructivist learning design. Beside the cost effectiveness, the features in Moodle like ability to expand with the student population; data analysis capabilities; and ability to meet the diverse needs of institutions, instructors, and learners, makes Moodle suitable for the new tutors.

The result works accordingly with Sallam and Alzouebi' finding (2014). They stated that all the teachers agreed that the implementation of Moodle as a learning management system would help them address children according to their individual learning levels and abilities. They all agreed that Moodle would provide a platform where they can design questions and activities that are suitable for each and every child's needs.

\subsubsection{Convenient Assessment Tools}

Based on the research result by Jeljeli, et al (2018), as to performance, students perceived assessments delivered over Moodle as most effective and having the best chance of improving their performance.

This finding supported the result of this research where new tutors find that the assessment tools in Moodle is convenient for them. Fifty percent of the participants are strongly agreed that they can make assessment of students' performance easily and they also agreed that they can change or add assessment based on their needs.

Moreover, Padayachee's research result (2017) showed the convenient assessment of Moodle by reporting educators and the students who can see the marks obtained for assessments and the progress made. Educators can view students' submissions. Some of the data extracts pertaining to the usefulness of this subtheme 
were tracks student progress and track student submissions. Tracking students' marks is useful as they can see all their marks and how they are doing.

\subsection{Suggestion from New Tutors}

Even though the result show that the new tutors felt the advantages of Moodle, they also suggested some features to be added to improve the teaching learning activity.

The new tutors expect that there is feedback feature in the discussion. They feel difficulties in replying the students' answer because it can only be answered by one person. It would be problem if there are other students who want to join in their friends' discussion.

Other participants also explained about the lack of mathematics symbol in Moodle. For new tutors who manage online tutorial in science and math field, the lack of mathematics symbol makes them difficult to explore the subject and.

The other participants also commented about the students' assignment that is not appeared even though it has been uploaded. This kind of error makes them anxious whether the students already collected the assignment or not. To improve the quality of the online tutorial and teaching learning activity itself, the new tutors suggested several things in the Moodle features.

When checking the discussion, there are some students who have been found cheating or copying their friends answer in the discussion forum. So, for the new tutors, it will be helpful if there is plagiarism checker feature on the Moodle. It will be easier for the tutors to track the students' work and give a fair assessment to them.

Other suggestion is to provide information about what subjects that students are enrolling at that time. The tutors will know easily if the students try to reach and contact them without asking them in the first place.

The tutors also want to have video conference feature on Moodle. This will be very helpful for students in Universitas Terbuka, because our stduents is widepsread all over Indonesia. We have 36 regional offices which make us separated by place and time. In addition, the limitation of discussion through one door, so students can only reply friends' opinion without starting the new conversation. The tutors also want the assignment upload feature to be fixed because it is become error often and it will make the assessment hampered.

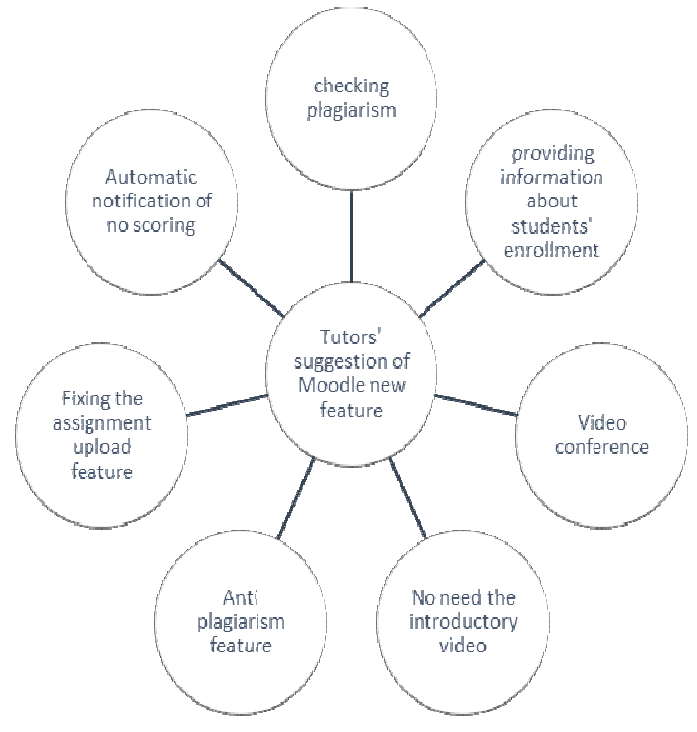

Diagram 1. Suggestion from New Tutors

The tutors also suggested Moodle to have feature on knowing the assignment or discussion that have not been scored by tutors, without checking it one by one. Sometimes, the tutors already went to the next session, but the students just answered the previous discussion. The tutors must check it to the last sessions to make sure their answer is scored.

The e-learning software platform, like Moodle, provides a variety of features that are installed in it to support the teaching learning process. New tutors' perspective in using Moodle is very important to be discussed because they are the main actor who arrange the lesson in the online tutorial.

\section{CONCLUSION AND SUGGESTION}

This research concluded that the new tutors' perspective on Moodle performance is shown in 3 main areas in term of userfriendliness, simple modification feature, and convenient assessment tools. However, the new tutors also give suggestion for the feature they wish to have in the Moodle platform to improve the teaching learning activity in the online tutorial scheme. The suggestions including the addition of plagiarism checker feature, improvement of the assignment upload system, video conference platform, and automatic notification of scoring. 
Siti Hadianti

NEW TUTORS' PERSPECTIVE ON MOODLE PERFORMANCE: A CASE STUDY IN ...

REFLEKSI EDUKATIKA : Jurnal Ilmiah Kependidikan, Volume 11, Nomor 1, Desember 2020, hlm. 35-39

\section{REFERENCES}

Chewe, P. 2018. Faculty perception of Moodle software as a teaching tool at the University of Zambia. Zambia Information Communication Technology (ICT) Journal, 2 (1): 25-34.

Cole, J., Foster, H. 2008. Using Moodle Teaching with the Popular Open Source Course Management System, O.R. Media, Editor: United Sates of America.

Creswell, John W. 2014. Research Design: Qualitative, Quantitative, and Mixed methods Approaches. London: Sage Publication.

Dey, I. 1993. Qualitative Data Analysis: A UserFriendly Guide for Social Scientists. London: Routledge.

Domenico, E. B. L d., and C. R. Cohrs. 2016. "Moodle platform for the construction of knowledge in intensive care: an experimental study". Acta Paul Enferm, 29 (4): $381-389$.

Florian, T. 2010. Confidence-based assessment in Moodle: Insights from teachers, administrators, and programmers. Retrieved from http://www.proquest.com/

Jebari, K., Boussedra, F., Ettouhami, A. 2017. Teaching "Information Systems Management" with Moodle. Internasional Journal of Emerging Technologies in Learning, 12 (4) : 4-16.
Jeljeli, Alnaji, L., Khazam, K. 2018. A Comparison between Moodle, Facebook, and Paper-based Assessment Tools: Students' Perception of Preference and Effect on Performance. Internasional Journal of Emerging Technologies in Learning, 13 (5): 86-99.

Moodle, 2015. Moodle.org. Retrieved 3.3.2020 from https://moodle.org/

Padayachee, I. 2017. Educator perceptions of virtual learning system quality characteristics. South African Computer Journal (SACJ), 29 (3): 95-126.

Sallam, N. and Alzouebi, K. 2014. Teacher Perceptions of the Use of Moodle to Enhance the Quality of Teaching and Learning in a K-12 Private School in the United Arab Emirates. Journal of Teaching and Teacher Education, 2 (2): 93-102.

Wihadanto, A., Mardoni, Y., Elysia, V., \& Efendi, Y. 2016. 'E-Learning' Literacy Tutor Tutorial Online Universitas Terbuka: Pengembangan Indikator Pengukuran. Institusi Pendidikan Tinggi di Era Digital: Pemikiran, Permodelan, dan Praktek Baik.

Yildiz, E.P., Tezer, M., Uzunboylu, H. 2018. Student Opinion Scale Related to Moodle LMS in an Online Learning Environment: Validity and Reliability Study. International Journal of Interactive Mobile Technologies, 12 (4): 97-108. 